\title{
FRUIT QUALITY OF WEST INDIAN CHERRY IRRIGATED WITH SALINE WATERS UNDER COMBINATIONS OF NITROGEN/POTASSIUM FERTILIZATION
}

\author{
QUALIDADE DE FRUTOS DE ACEROLEIRA IRRIGADA COM ÁGUAS SALINAS \\ SOB COMBINAÇÕES DE ADUBAÇÃO NITROGENADA/POTÁSSICA
}

\section{Evandro Manoel da SILVA ${ }^{1}$; Hans Raj GHEYI ${ }^{2}$; Reginaldo Gomes NOBRE ${ }^{3}$; Joicy Lima BARBOSA ${ }^{4}$; Bárbara Genilze Figueiredo Lima SANTOS ${ }^{5}$;} Sabrina Gomes de OLIVEIRA ${ }^{5}$; Elcimar Lopes da SILVA ${ }^{\mathbf{5}}$; Maria Amanda GUEDES ${ }^{5}$

1. Doutorando em Engenharia Agrícola, Programa de Pós-graduação em Engenharia Agrícola, Universidade Federal de Campina Grande - UFCG, Campina Grande, PB, Brasil. evandroagroman@hotmail.com; 2. Professor Visitante Doutor, Universidade Federal do Recôncavo da Bahia - UFRB, Cruz das Almas, BA, Brasil; 3. Professor Doutor, Universidade Federal Rural do Semi-Árido - UFERSA, Caraúbas, RN, Brasil; 4. Mestranda em Agronomia, Programa de Pós-graduação em Agronomia, Universidade Federal de Alagoas UFAL, Rio Largo, AL, Brasil; 5. Graduando em Agronomia, Unidade Acadêmica de Ciências Agrárias, UFCG, Pombal, PB, Brasil.

\begin{abstract}
West Indian cherry stands out among the fruits cultivated for the pharmacological and alimentary importance, but its quality can be affected by irrigation water salinity and fertilization management. In this context, this study aimed to evaluate the effect of irrigation water of different salinities and combinations of nitrogen and potassium fertilization on the physical and physico-chemical quality of bioactive compounds in West Indian cherry fruits. The experiment was carried out in the field, using lysimeters of $60 \mathrm{~L}$, in the Experimental Area of the Centro de Ciências e Tecnologia Agroalimentar (CCTA) of Universidade Federal de Campina Grande (UFCG), Pombal, PB, in a randomized block design, with treatments arranged in a $5 \times 4$ factorial scheme, referring to five irrigation water salinities (ECW): $0.3,1.3,2.3,3.3$ and $4.3 \mathrm{dS} \mathrm{m}^{-1}$ and four combinations $(\mathrm{C})$ of doses of nitrogen $(\mathrm{N})$ and potassium $\left(\mathrm{K}_{2} \mathrm{O}\right): \mathrm{C} 1=70 \% \mathrm{~N}+50 \% \mathrm{~K}_{2} \mathrm{O} ; \mathrm{C} 2=100 \% \mathrm{~N}+$ $75 \% \mathrm{~K}_{2} \mathrm{O} ; \mathrm{C} 3=130 \% \mathrm{~N}+100 \% \mathrm{~K}_{2} \mathrm{O}$ and $\mathrm{C} 4=160 \% \mathrm{~N}+125 \% \mathrm{~K}_{2} \mathrm{O}$, of the recommended dose for West Indian cherry, with three replicates and one plant per plot consisting of a lysimeter. The cv. Flor Branca grafted on cv. Junco was used in the study. The increase in salinity of irrigation water reduced the size, weight and vitamin $\mathrm{C}$ content of the fruits, but, the combinations of $\mathrm{N}$ and $\mathrm{K}$ fertilization did not affect fruit shape and the content of anthocyanin, carotenoids, $\mathrm{pH}$, titratable acidity, total soluble solids and fruit flavor. Fertilization combinations consisting of $\mathrm{C} 1$ and $\mathrm{C} 2$ treatments promoted the largest fruit size under irrigation with ECw of up to $1.3 \mathrm{dS} \mathrm{m}^{-1}$ and greater mass accumulation. Fertilization doses above $\mathrm{C} 2$ combinations negatively affected fruit quality.
\end{abstract}

KEYWORDS: Malpighia emarginata D. C. Salinity. Nutrition. Post-harvest.

\section{INTRODUCTION}

West Indian cherry (Malpighia emarginata D. C.) is considered as one of the most interesting fruits in the Brazilian Northeast region, due to its physico-chemical characteristics and its bioactive compounds for pharmacological and alimentary use (FACHI et al., 2016), standing out for its elevated contents of vitamin $\mathrm{C}$ and other compounds with antioxidant properties, such as carotenoids, anthocyanin and phenolics, placing this species in a prominent position among the fruit species cultivated in the region (ARAÚJO et al., 2009).

It is worth noting that the quality parameters of the West Indian cherry, such as the vitamin C content, color, weight, size, total soluble solids and pulp $\mathrm{pH}$ are affected by the genetic variability of the orchard and may also be influenced by several other factors, such as pluvial precipitation, temperature elevation, fertilization management, irrigation and salinity (FACHI et al., 2016).

The semiarid region of the Brazilian Northeast has high evapotranspiration demand and reduced rainfall levels, with limited availability of good quality water, often resulting in the use of water with high levels of salts for irrigation, inducing morphological, structural and metabolic changes in the crops (GURGEL et al., 2010), with negative effects on production, physical and physico-chemical characteristics and on the bioactive compounds of the fruits (DIAS et al., 2011). However, it is worth noting that yield and quality losses in the plants, as a consequence of salinity, vary among species and cultivars that have distinct physiological behavior, depending on the phenological stage of the crop, duration of the 
Fruit quality of west...

exposure to salt stress, type of salts in the substrate and intensity of soil management and crop fertilization (AYERS; WESTCOTT, 1999).

In this perspective, for obtaining quality fruits that satisfy the demands of consumers and of the pulp processing industry, especially in the Northeast semiarid region, where salt stress prevails, appropriate technologies must be adopted to satisfy their hydro-climatic, environmental and nutritional requirements, with the adoption of adequate management practices of fertilization and irrigation with water of high salt contents (DIAS et al., 2011).

The combination of adequate doses of nitrogen and potassium is one of these studied technologies, aiming to decrease the nutritional imbalance and the osmotic effects caused by salinity, and thus increasing plant tolerance to salt stress (GURGEL et al., 2010; ANDRADE JUNIOR et al., 2011).

The adequate concentration of $\mathrm{N}$ enhances the activity of enzymes involved in metabolic pathways, increases the production of amino acids, proteins, and phytohormones, and can promote the osmotic adjustment of plants to salinity (TAIZ et al., 2017). In turn, $K$ promotes the control of cell turgidity, regulation of opening and closing processes in stomata, activation of enzymes involved in cellular respiration and photosynthesis, and the transport of carbohydrates and phytohormones, factors involved in the plants'

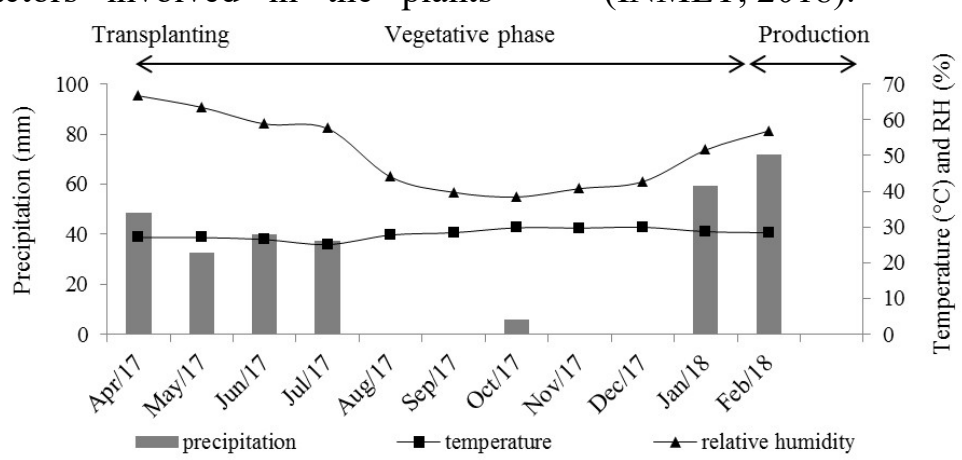

Figure 1. Mean data of precipitation, temperature and relative humidity - RH, in the study period between April 19, 2017 and February 13, 2018, obtained in an automated meteorological station located near the municipality of Pombal, PB (INMET, 2018).
The treatments were distributed in a $5 \times 4$ factorial design, referring to five salinity levels of the irrigation water $(\mathrm{ECw})$ of $0.3 ; 1.3 ; 2.3 ; 3.3$ and $4.3 \mathrm{dS} \mathrm{m}^{-1}$ and four combinations (C) of nitrogen (N) and potassium $\left(\mathrm{K}_{2} \mathrm{O}\right)$ doses based on recommendation of fertilization for the West Indian cherry (CAVALCANTI, 2008): $\mathrm{C} 1=70 \% \mathrm{~N}+50 \%$ $\mathrm{K}_{2} \mathrm{O} ; \mathrm{C} 2=100 \% \mathrm{~N}+75 \% \mathrm{~K}_{2} \mathrm{O} ; \mathrm{C} 3=130 \% \mathrm{~N}+$ $100 \% \mathrm{~K}_{2} \mathrm{O}$ and $\mathrm{C} 4=160 \% \mathrm{~N}+125 \% \mathrm{~K}_{2} \mathrm{O}$. The experimental design was in randomized blocks, with response to salinity stress (WANG et al., 2013), and photoassimilates to the fruits, thus affecting quality attributes (VIDIGAL et al., 2009).

Furthermore, nitrogen and potassium are the most required and extracted macronutrients by the West Indian cherry fruits (FERREIRA, 2014). However, with regard to the effect of these nutrients and salt stress on the fruit quality of this crop, studies are still incipient. In this perspective, this study aimed to evaluate the effect of the irrigation water salinity and different combinations of nitrogen and potassium fertilization on the physical, physicochemical characteristics and bioactive compounds in fruits of West Indian cherry.

\section{MATERIAL AND METHODS}

West Indian cherry plants were cultivated in the Experimental Area belonging to the Centro de Ciências e Tecnologia Agroalimentar (CCTA) of Universidade Federal de Campina Grande (UFCG), Pombal, PB, during the period between April 19, 2017, and February 13, 2018, in 60 L lysimeters. The reference geographic coordinates of the place are 6 $6^{\circ} 48^{\prime} 16^{\prime \prime}$ South latitude, 37\%49'15" West longitude, with an average elevation of $144 \mathrm{~m}$. The climatological data of the study area during the experimental period are presented in Figure 1 (INMET, 2018).

Production is able to aid in the synthesis and transport of

three replications, each being composed of a lysimeter containing one plant, totalizing 60 lysimeters in the experiment.

The tested salt levels were based on a previous study conducted by Sá et al. (2018), who verified that the irrigation with water salinity up to $2.2 \mathrm{dS} \mathrm{m}^{-1}$ did not compromise the growth and physiology of the West Indian cherry cv. BRS 336 Jaburu. 
Fruit quality of west...

The saline waters of the treatments from 1.3 to $4.3 \mathrm{dS} \mathrm{m}^{-1}$ were prepared following the relationship between $\mathrm{ECW}$ and salt concentration $\left.\left(\mathrm{mmol}_{\mathrm{c}} \mathrm{L}^{-1}=\mathrm{EC}(\mathrm{dS} \mathrm{m})^{-1}\right) \times 10\right)$ by the addition of $\mathrm{NaCl}, \mathrm{CaCl}_{2} \cdot 2 \mathrm{H}_{2} \mathrm{O}$ and $\mathrm{MgCl}_{2} \cdot 6 \mathrm{H}_{2} \mathrm{O}$, maintaining the equivalent proportion of $7: 2: 1$, respectively. The water of the treatment with the lowest salinity $(0.3$ $\mathrm{dS} \mathrm{m}^{-1}$ ) was originated from the Coremas-Mãe d'Água reservoir, which supplies water for drinking and irrigation purposes in the region. The proportion of salts utilized in the preparation of the irrigation waters is predominant in the main water sources used for irrigation in the Brazilian Northeast (MEDEIROS, 1992).

The fertilizer recommendation for the West Indian cherry cultivar Flor Branca cultivated under irrigated conditions was adopted, corresponding to $100 \mathrm{~g}$ of $\mathrm{N}$ and $80 \mathrm{~g}$ of $\mathrm{K}_{2} \mathrm{O}$ per plant per year (CAVALCANTI, 2008), equivalent to the doses of treatments of $100 \%$ of nitrogen and potassium. Following this recommendation, the $\mathrm{N}$ and $\mathrm{K}_{2} \mathrm{O}$ doses were determined and split into 24 applications at the interval of 15 days for the first crop year (360 days).

However, during the first harvest (until 295 DAT), 19 applications of $\mathrm{N}$ and $\mathrm{K}_{2} \mathrm{O}$ were performed, in equal parts, every 15 days, resulting in the application of $79.17 \mathrm{~g}$ of $\mathrm{N}$ and $63.33 \mathrm{~g}$ of $\mathrm{K}_{2} \mathrm{O}$, per plant, corresponding to the doses of $100 \%$ nitrogen and potassium. Urea $(45 \% \quad \mathrm{~N})$ and potassium chloride $\left(60 \% \mathrm{~K}_{2} \mathrm{O}\right)$ were utilized as $\mathrm{N}$ and $\mathrm{K}$ sources, respectively.

Phosphate fertilization was performed by applying $20 \mathrm{~g}$ of $\mathrm{P}_{2} \mathrm{O}_{5}$ per plant, determined in accordance with the phosphorus availability in the soil, after chemical analysis, utilizing single superphosphate $\left(18 \% \mathrm{P}_{2} \mathrm{O}_{5}\right)$ in a single application before the transplanting, mixing the fertilizer to the
SILVA, E. M.et al.

soil of each lysimeter, following the recommendation for the fertilization of the irrigated West Indian cherry cultivar Flor Branca (CAVALCANTI, 2008).

The seedlings of West Indian cherry cv. Junco were provided by a commercial plant nursery registered under the National Register of Seeds and Seedlings, located in the district of São Gonçalo, Sousa - PB, cultivated in polyethylene bags with dimensions of $10 \times 20 \mathrm{~cm}$ and volumetric capacity of $0.5 \mathrm{~L}$, cleft grafted by using scion of the cultivar Flor Branca.

These cultivars are adapted to the edaphoclimatic conditions of the semiarid region of Northeastern Brazil, being among the most planted cultivars in irrigated perimeters of the São Francisco, characterized for initiating production at 6 months after transplanting under irrigation, and yields of up to $100 \mathrm{~kg} \mathrm{plant}^{-1}$ year $^{-1}$, fruits with redcolor skin, weighing between 3 and $5 \mathrm{~g}$, and vitamin $\mathrm{C}$ content over $1.000 \mathrm{mg} 100 \mathrm{~g}^{-1}$ of pulp (CALGARO; BRAGA, 2012).

Seedlings were transplanted when they reached 30 to $40 \mathrm{~cm}$ height at 120 days after grafting into $60 \mathrm{~L}$ lysimeters, spaced in the field by $1.2 \times 2.0 \mathrm{~m}$ within and between planting rows, respectively. The lysimeters received in their base a drainage system, consisting of a drain with $1 / 2$ " diameter $(12.7 \mathrm{~mm})$ tube inserted in the base extremity, followed by a $3.0 \mathrm{~cm}$ thick layer of gravel and a $2.0 \mathrm{~cm}$ thick layer of washed sand. Over the sand, $56 \mathrm{~L}$ of soil collected in the $0-20 \mathrm{~cm}$ layer from Plot 14, Sector I, of the Irrigated Perimeter of Várzeas de Sousa-PB, were placed. The physical and chemical attributes (Table 1) of the soil were determined in the Laboratory of Irrigation and Salinity of the CCTA/UFCG, Pombal, PB.

Table 1. Physical and chemical attributes of the soil used in the experiment

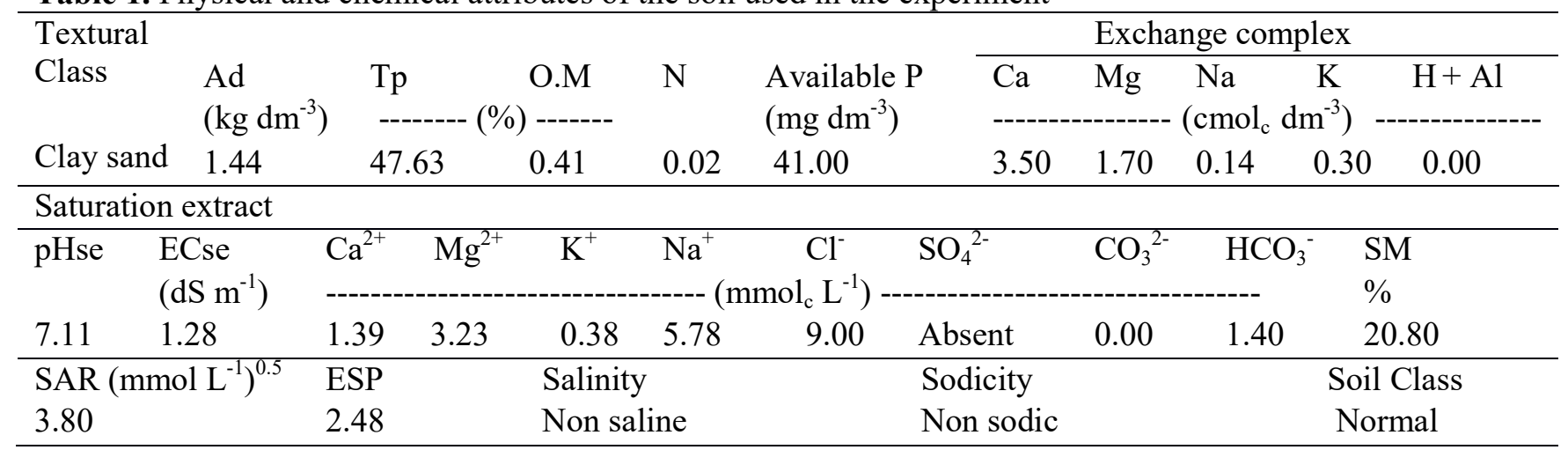

Ad - Apparent density; Tp - Total porosity; O.M. - Organic matter estimated by Walkley-Black wet digestion; $\mathrm{pHse}$ - $\mathrm{pH}$ of the saturation extract; ECse - Electrical conductivity of the soil saturation extract at $25^{\circ} \mathrm{C}$; SM - Saturated soil moisture content $(\%$ based on mass); SAR - Sodium adsorption ratio; ESP - Exchangeable sodium percentage; $\mathrm{P}, \mathrm{K}$ and $\mathrm{Na}$ extracted by Mehlich-1; Ca and Mg extracted by $1.0 \mathrm{M} \mathrm{KCl}$ at $\mathrm{pH} 7.0 ; \mathrm{H}+\mathrm{Al}$ extracted by $0.5 \mathrm{M} \mathrm{CaOAc}$ at $\mathrm{pH} 7.0$. 
After the transplanting of the seedlings into the lysimeters, a $4.0 \mathrm{~cm}$ thick layer of mulch composed of grass remains was applied over the soil previously irrigated and at moisture content equivalent to field capacity, aiming to minimize water losses through evaporation. Wooden sticks of $1.0 \mathrm{~cm}$ diameter and $80 \mathrm{~cm}$ length were utilized for holding the plants in a vertical position to avoid lodging.

The application of the fertilizer combinations, according to the treatments, began at 20 DAT, simultaneously performed by topdressing through the conventional method, in a circle with 20 $\mathrm{cm}$ radius from the base of the plant.

Initially, until 40 DAT, the plants were irrigated with water of electrical conductivity of 0.3 $\mathrm{dS} \mathrm{m} \mathrm{m}^{-1}$, to promote good acclimatization to field conditions. The application of the saline water treatments began at 41 DAT, through daily manual irrigation with the respective water treatment and based on the principle of drainage lysimetry, where the volume to be applied in each irrigation was determined by the difference between the applied and the drained volume, the value of this difference being considered equivalent to the water volume necessary for the soil to reach maximum water retention capacity (field capacity). A leaching fraction of 0.15 at every 15 days was adopted, aiming to decrease the excessive accumulation of salts in the root zone of the plants, the leaching volume being determined based on the volume applied in this period.

The plants were conducted in single stem from the transplanting, and the apical bud was removed when plants reached $50 \mathrm{~cm}$ height (around 70 DAT), thus simulating the growth of the lateral buds. From the emerging lateral branches, only three branches were allowed to grow at different heights, radially distributed in the terminal $20 \mathrm{~cm}$ of the main stem, denominated as primary branches. During this process, all sprouts and poorly located branches were removed, especially those directed towards the soil.

Flowering began at five months after transplanting (150 DAT). However, due to their reduced size and flowering unevenness in the different experimental plots, manual elimination of the flowers was performed until 230 DAT. The beginning of the flowering period was considered from this time on for the evaluation of the first production cycle of crop.

The following physical parameters were evaluated in the fruits: equatorial fruit diameter (EFD), polar fruit diameter (PFD), fruit average size (FAS), fruit average mass (FAM) and fruit shape
(FS). These parameters were obtained in fruits originated from harvests performed during the first production cycle, at a three-day interval, in the period from 260 (January 8, 2018) to 295 DAT (February 13, 2018). The fruits that showed an intense redcolored skin were collected; this characteristic is the fruit maturation standard of the cultivar Flor Branca (CALGARO; BRAGA, 2012).

The measures of EFD and PFD were performed in a representative sample of 20 harvested fruits per plant, randomly selected from the total obtained in each harvest. The EFD was measured in the median region as the fruit width, and the PFD was measured from the base to the apex of the fruit, with the aid of a digital caliper. The FAS was obtained by the mean of the EFD and PFD, and the FAM was determined by dividing the total mass of fruits produced per plant by the total number of fruits, which were weighed on a precision balance $(0.01 \mathrm{~g})$. As for the FS, the value was obtained as the ratio between the polar diameter/equatorial diameter of the fruits.

The physico-chemical characteristics and the bioactive compounds were evaluated in fruits harvested at 295 DAT, when they showed the same previously cited maturation standard. The fruits were packed in polyethylene bags containing $250 \mathrm{~g}$ each and stored in black polyethylene bags, immediately subjected to freezing in a freezer at a temperature of $20{ }^{\circ} \mathrm{C}$ for 120 days. Afterwards, the pulp was extracted and processed in a domestic food processor in the Chemistry, Biochemistry and Food Analysis Laboratory of the CCTA/UFCG for the analysis of following physico-chemical parameters: hydrogen potential $(\mathrm{pH})$, titratable acidity - \% of citric acid (TA), total soluble solids - ${ }^{\circ}$ Brix (TSS), total soluble solids/titratable acidity ratio (TSS/TA); and bioactive compounds: total carotenoids - mg $100 \mathrm{~g}^{-1}$ (Car), anthocyanin - $\mu \mathrm{g} \mathrm{g}^{-1}$ (Ant) Vitamin $\mathrm{C}-\mathrm{mg}$ of ascorbic acid $100 \mathrm{~g}^{-1}$ of pulp (Vit C).

The $\mathrm{pH}$ was determined through direct reading in the extract of the West Indian cherry fruits with a digital laboratory potentiometer. The TA was measured in $10 \mathrm{~g}$ of pulp homogenized in $10 \mathrm{~mL}$ of distilled water. The solution containing the sample was titrated with $\mathrm{NaOH} 0.1 \mathrm{~N}$ until reaching the turning point of the phenolphthalein indicator, being expressed as a percentage of citric acid (IAL, 2008). The TSS were determined in the pulp extract of the West Indian cherry fruits, with an automatic temperature compensation digital refractometer calibrated with distilled water whenever necessary. The TSS/TA ratio was obtained by dividing the soluble solids values by the titratable acidity values. 
The carotenoids and anthocyanin contents were determined by the method of Sims and Gamon (2002). $1.0 \mathrm{~g}$ of the sample was weighed and $3 \mathrm{~mL}$ of the extractor, prepared in $80 \%$ buffered acetone with Tris- $\mathrm{HCl} 0.2 \mathrm{M} \mathrm{pH} \mathrm{7.8,} \mathrm{was} \mathrm{added} \mathrm{and}$ homogenized for 3 minutes. Afterwards, the samples were centrifuged at $10{ }^{\circ} \mathrm{C}$ and $3.000 \mathrm{rpm}$ for 10 minutes in a refrigerated centrifuge, and the supernatants were read in spectrophotometer at the wavelengths of 470 and $537 \mathrm{~nm}$ for carotenoids and anthocyanin, respectively. The vitamin $\mathrm{C}$ content was estimated by titration, utilizing $0.5 \mathrm{~g}$ of pulp added to $49.5 \mathrm{~mL}$ of oxalic acid at $0.5 \%$ and titrated with Tillmans' solution until reaching a pink color (IAL, 2008).

The means of the variables were subjected to analysis of variance by the $F$ test, at 0.05 and 0.01 probability levels, with the data of the water salinity levels being analyzed by polynomial regression, and the means of the combination of nitrogen and potassium doses by Tukey's mean test at 0.05 probability level, utilizing the statistical software SISVAR/UFLA for data processing (FERREIRA, 2011).

\section{RESULTS AND DISCUSSION}

By analyzing the physical parameters of the West Indian cherry fruits, it can be verified (Table 2) that the interaction between the irrigation water salinity and the combination of the NK fertilization was significant $(p<0.05)$ for the EFD and the FAS. Likewise, a single significant effect $(p<0.05)$ of the irrigation water salinity and the combination of the NK fertilization on the PFD and FAM is observed. Further, it is verified that the FS was not affected ( $p$ $>0.05$ ) by any of the studied factors.

Table 2. Summary of the analysis of variance for the equatorial (EDF) and polar fruit diameters (PFD), fruit average size (FAS), fruit average mass (FAM) and fruit shape (FS) of the West Indian cherry plants irrigated with waters of different salinities, under combinations of nitrogen and potassium fertilization, from harvests performed in the first production cycle, between 260 and 295 days after transplanting.

\begin{tabular}{lllllll}
\hline \multirow{2}{*}{ Source of variation } & \multicolumn{5}{l}{ Mean square } \\
\cline { 2 - 7 } & DF & EFD & PFD & FAS & FAM & FS \\
\hline Salinity (S) & 4 & $3.6286^{* *}$ & $1.4918^{*}$ & $2.3260^{* *}$ & $1.6105^{* *}$ & $0.0016^{\mathrm{NS}}$ \\
NK Combinations (C) & 3 & $6.959^{* *}$ & $3.1073^{* *}$ & $4.7711^{* *}$ & $2.0206^{* *}$ & $0.0015^{\mathrm{NS}}$ \\
Interaction S*C & 12 & $1.4589^{*}$ & $0.5911^{\mathrm{NS}}$ & $0.9283^{*}$ & $0.4364^{\mathrm{NS}}$ & $0.0008^{\mathrm{NS}}$ \\
Blocks & 2 & $0.6271^{\mathrm{NS}}$ & $1.9165^{*}$ & $0.8585^{\mathrm{NS}}$ & $0.3664^{\mathrm{NS}}$ & $0.0045^{\mathrm{NS}}$ \\
Residual & 38 & 0.7119 & 0.4631 & 0.4426 & 0.2341 & 0.0013 \\
$\mathrm{CV}(\%)$ & - & 4.50 & 4.07 & 3.75 & 14.08 & 4.00 \\
Mean & - & $18.76 \mathrm{~mm}$ & $16.73 \mathrm{~mm}$ & $17.75 \mathrm{~mm}$ & $3.44 \mathrm{~g}$ & 0.89 \\
\hline NS, ${ }^{*}$ and ** Not significant and significant at $\mathrm{p}<0.05$ and $\mathrm{p}<0.01$, respectively; DF - Degrees of freedom; CV - Coefficient of \\
variation.
\end{tabular}

With regard to the analysis of the interaction of the water salinity within each combination of NK fertilization, it is verified that the EFD (Figure 2A) and the FAS (Figure 2 B) linearly decreased with the increase in the irrigation water salinity, when the plants were fertilized with the $\mathrm{C} 1$ and $\mathrm{C} 2$ combinations, whose decrease in the EFD, according to the regression equations, were 2.86 and $2.63 \%$, per unit increase in the ECw. As for the FAS, the reductions corresponded to 2.57 and $2.27 \%$ with the fertilization with $\mathrm{C} 1$ and $\mathrm{C} 2$ combinations, respectively, for each unit increment of the $\mathrm{ECw}$.

The decrease in fruit size and diameter with the increase in the $\mathrm{ECw}$, in the plants fertilized with the $\mathrm{C} 1$ and $\mathrm{C} 2$ combinations, might be related to the osmotic effects of the salts in the irrigation water, which usually cause reduction in water absorption and in the photosynthetic rates by the plants, resulting in losses in the cell elongation and division rates of the growing fruits and decrease in the accumulation of photoassimilates (WILLADINO; CAMARA, 2010; TAIZ et al., 2017).

It can also be observed, in Figures $2 \mathrm{~A}$ and $2 \mathrm{~B}$, that in the plants fertilized with the $\mathrm{C} 3$ and $\mathrm{C} 4$ combinations, the EFD and the FAS were not affected $(p>0.05)$ by the increase in water salinity, in which the EFD maintained mean values of 18.33 and $18.05 \mathrm{~mm}$, and the FAS maintained mean values of 17.33 and $17.20 \mathrm{~mm}$, in the plants fertilized with C3 and C4, respectively. Such phenomenon might have occurred because the higher $\mathrm{N}$ and $\mathrm{K}$ doses compromised fruit growth in the plants irrigated with the lowest saline levels, mainly in those irrigated with the $\mathrm{ECw}$ of 0.3 and $1.3 \mathrm{dS} \mathrm{m}^{-1}$, with fruit size similar to those of the 
plants irrigated with the highest saline levels (2.3; 3.3 and $4.3 \mathrm{dS} \mathrm{m}^{-1}$ ).

(A)

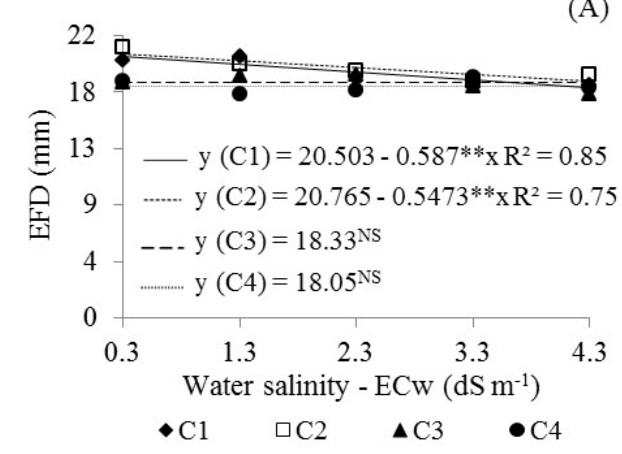

(B)

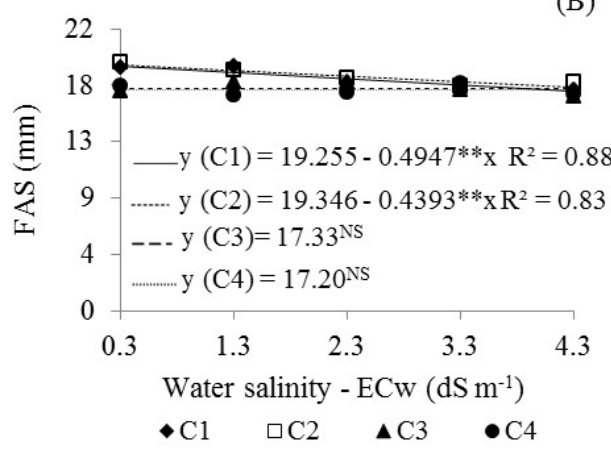

Figure 2. Follow-up analysis of the salinity of the irrigation water within the combinations of nitrogen and potassium fertilization for the equatorial fruit diameter - EFD (A) and fruit average size - FAS (B) of the West Indian cherry plants irrigated with saline waters, from harvests performed in the first production cycle, between 260 and 295 days after transplanting.

$\mathrm{C} 1=70 \% \mathrm{~N}+50 \% \mathrm{~K}_{2} \mathrm{O} ; \mathrm{C} 2=100 \% \mathrm{~N}+75 \% \mathrm{~K}_{2} \mathrm{O} ; \mathrm{C} 3=130 \% \mathrm{~N}+100 \% \mathrm{~K}_{2} \mathrm{O}$ and $\mathrm{C} 4=160 \% \mathrm{~N}+125 \% \mathrm{~K}_{2} \mathrm{O}$ of the recommendation.

These results indicate that high doses of $\mathrm{N}$ and $\mathrm{K}$, applied in plants irrigated with low salinity water, may be as harmful on the physical attributes of the West Indian cherry fruits as high salinity levels. It may also be related to nutritional imbalance, considering that very high doses of $\mathrm{N}$ can reduce the content of $\mathrm{K}$ in plant tissues as a consequence of the competitive effect between $\mathrm{NH}_{4}{ }^{+}$ and $\mathrm{K}^{+}$(BATISTA; MONTEIRO, 2010), and high $\mathrm{K}^{+}$concentrations may decrease the absorption of $\mathrm{Ca}^{2+}$ by the plants, intensifying the nutritional imbalance and cell growth (INTHICHACK; NISHIMURA; FUKUMOTO, 2012).

By investigating the follow-up analysis of the combination of the NK fertilization within each irrigation water salinity, it is seen (Figures 3A and $3 \mathrm{~B})$ that the $\mathrm{C} 1$ and $\mathrm{C} 2$ combinations, when the plants were irrigated with water salinity levels of 0.3 and $1.3 \mathrm{dS} \mathrm{m}^{-1}$ led to higher values of the EFD (20.10, 21.08, 20.34 and $18.37 \mathrm{~mm}$, respectively) and FAS (18.96, 19.42, 19.04 and $17.87 \mathrm{~mm}$, respectively).
(A)

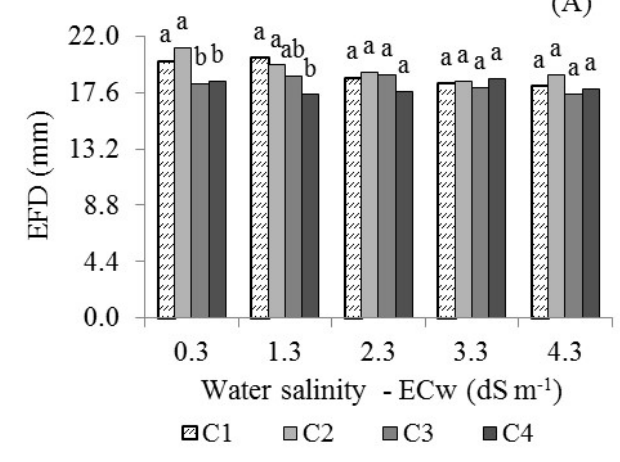

(B)

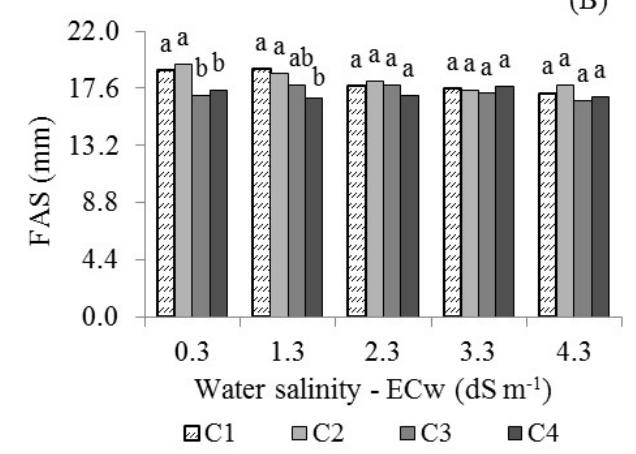

Figure 3. Follow-up analysis of combinations of nitrogen and potassium fertilization within the salinity of the irrigation water for the equatorial fruit diameter - EFD (A) and fruit average size - FAS (B) of the West Indian cherry plants irrigated with saline waters, from harvests performed in the first production cycle, between 260 and 295 days after transplanting - DAT.

$\mathrm{C} 1=70 \% \mathrm{~N}+50 \% \mathrm{~K}_{2} \mathrm{O} ; \mathrm{C} 2=100 \% \mathrm{~N}+75 \% \mathrm{~K}_{2} \mathrm{O} ; \mathrm{C} 3=130 \% \mathrm{~N}+100 \% \mathrm{~K}_{2} \mathrm{O}$ and $\mathrm{C} 4=160 \% \mathrm{~N}+125 \% \mathrm{~K}_{2} \mathrm{O}$ of the recommendation. Means followed by different letters indicate significant difference in the respective treatment of water salinity by Tukey's test ( $\mathrm{p}<0.05$ probability). 
Fruit quality of west...

It is possible that the lowest doses of $\mathrm{N}$ and $\mathrm{K}$, from the $\mathrm{C} 1$ and $\mathrm{C} 2$ combinations, were favorable for the higher nutritional balance in the plants irrigated with water with electrical conductivity of 0.3 and $1.3 \mathrm{dS} \mathrm{m}^{-1}$, levels up to which the plants could osmotically adjust, with positive effect on the EFD and FAS.

It is worth noting that at these $\mathrm{ECw}$ levels, the fertilization with the $\mathrm{C} 3$ and $\mathrm{C} 4$ combinations decreased the EFD (means of 18.33 and $18.49 \mathrm{~mm}$ ) and the FAS (17.09 and $17.49 \mathrm{~mm}$, respectively) in relation to the fruits from the plants fertilized with $\mathrm{C} 1$ and $\mathrm{C} 2$ (Figures $3 \mathrm{~A}$ and $3 \mathrm{~B}$ ) combinations, demonstrating the previous arguments for the harmful effects of high $\mathrm{N}$ and $\mathrm{K}$ doses on the fruit size of plants irrigated with low-salinity water.
SILVA, E. M.et al.

The fertilization with distinct combinations of NK fertilization in the plants irrigated with $\mathrm{ECw}$ of $2.3 ; 3.3$ and $4.3 \mathrm{dS} \mathrm{m} \mathrm{m}^{-1}$, did not promote significant difference in the EFD and FAS, demonstrating that the $\mathrm{N}$ and $\mathrm{K}$ combinations, applied above the recommended dose, were not efficient in mitigating the effects of the irrigation water salinity on the fruit size and transversal diameter at these ECw levels.

For the PFD, it is verified (Figure 4A) that its values were reduced with the increase in the irrigation water salinity, causing a decrease of $1.19 \%$ for each unit increase in the ECw. A similar effect can be observed on the FAM (Figure 4B), in which the negative effect of salinity was more intense, resulting in a loss of $5.41 \%$ per unit increment in water salinity.

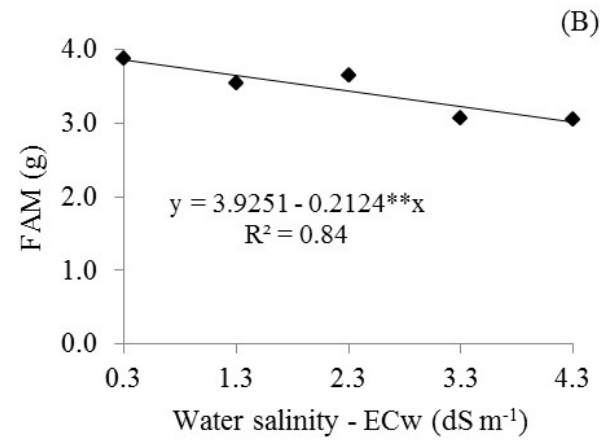

Figure 4. Polar fruit diameters - PFD (A) and fruit average mass - (FAM) of the West Indian cherry plants irrigated with saline waters, from harvests performed in the first production cycle, between 260 and 295 days after transplanting - DAT.

With regard to the FAM, it can be affirmed that its values, in the plants irrigated between 0.3 and $4.3 \mathrm{dS} \mathrm{m}^{-1}$, are within the average fruit mass for the cultivar Flor Branca, which generally varies from 3 to $5 \mathrm{~g}$ (CALGARO; BRAGA, 2012). However, under the conditions of the present work, it is noted (Figure 4B) that the plants irrigated with water of lowest salinity $\left(0.3 \mathrm{dS} \mathrm{m}^{-1}\right)$ had the highest mass accumulation in the fruits $(3.86 \mathrm{~g})$, being $28.24 \%$ superior to the value of $3.01 \mathrm{~g}$ of the plants irrigated with $\mathrm{ECw}$ of $4.3 \mathrm{dS} \mathrm{m}^{-1}$; this difference must be taken into consideration, because fruits with higher mass can provide a higher pulp yield and profitability for producer (FACHI et al., 2016).

As mentioned earlier, the decrease in these variables occurs as a consequence of the osmotic effect and of the ionic instability caused by the salt stress (NIVAS; GAIKWAD; CHAVN, 2011). Under these conditions, water absorption by the plants is decreased, negatively affecting growth and cellular division, as well as reducing the photosynthetic activity and the transport of photoassimilates, thus causing decrease in growth and mass accumulation (BEZERRA et al., 2018).

With regard to the combination effect of the NK fertilization on the PFD and FAM, it is observed (Figures 5A and 5B) that the fertilizations with the $\mathrm{C} 1$ and $\mathrm{C} 2$ combinations promoted highest polar diameter and mass accumulation in the fruits, whereas the values were decreased when plants were fertilized with the $\mathrm{C} 3$ and $\mathrm{C} 4$ combinations.

It is possible that the nitrogen and potassium doses, from the $\mathrm{C} 1$ and $\mathrm{C} 2$ combinations, provided a higher nutritional balance, favoring physiological and biochemical activities in the plants, with positive effect on fruit growth in diameter and on mass accumulation (TAIZ et al., 2017), because N, when applied at adequate concentrations, increases the activity of enzymes involved in metabolic pathways and increases the production of amino acids, proteins and phytohormones (TAIZ et al., 2017), whereas $\mathrm{K}$ is involved in osmotic and stomatal regulation and in the activation of enzymes involved in cellular respiration and photosynthetic 
activity (WANG et al., 2013), factors that promote the production of essential photoassimilates, which are stored in the fruits, organs that work as the main sink for photoassimilates (VIDIGAL et al., 2009).
(A)

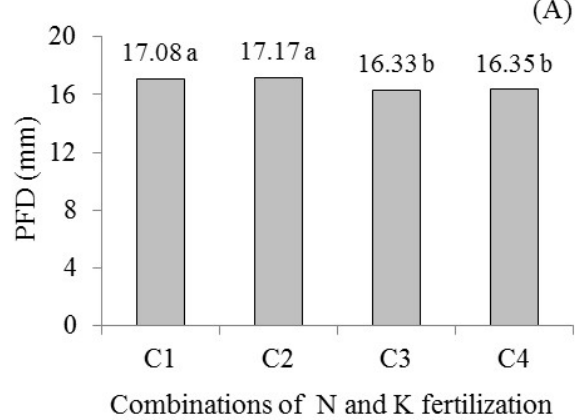

(B)

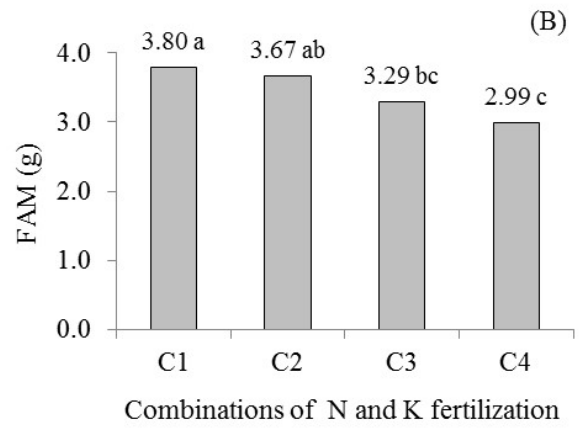

Figure 5. Polar fruit diameters - PFD (A) and fruit average mass - (FAM) of the West Indian cherry plants under different combinations of nitrogen and potassium fertilization, from harvests performed in the first production cycle, between 260 and 295 days after transplanting.

$\mathrm{C} 1=70 \% \mathrm{~N}+50 \% \mathrm{~K}_{2} \mathrm{O} ; \mathrm{C} 2=100 \% \mathrm{~N}+75 \% \mathrm{~K}_{2} \mathrm{O} ; \mathrm{C} 3=130 \% \mathrm{~N}+100 \% \mathrm{~K}_{2} \mathrm{O}$ and $\mathrm{C} 4=160 \% \mathrm{~N}+125 \% \mathrm{~K}_{2} \mathrm{O}$ of the recommendation. Means followed by different letters indicate significant difference between the treatments by Tukey's test ( $\mathrm{p}$ $<0.05$ probability).

With regard to the physico-chemical attributes and to the bioactive compounds of the West Indian cherry fruits, it is verified (Table 3 ) that there was no significant $(\mathrm{p}>0.05)$ interaction between the irrigation water salinity and the combination of the NK fertilization on the studied variables, as well as no single significant effect ( $\mathrm{p}>$ 0.05 ) of the irrigation water salinity and the combination of the NK fertilization, except significant $(\mathrm{p}<0.05)$ single effect of the irrigation water salinity on the Vit $\mathrm{C}$ content.

Table 3. Summary of the analysis of variance for anthocyanin (Ant), carotenoids (Car), hydrogen potential $(\mathrm{pH})$, titratable acidity (TA), total soluble solids (TSS), total soluble solids/titratable acidity ratio (TSS/TA) and vitamin C (Vit C) content in fruits of the West Indian cherry plants irrigated with waters of different salinities, under combinations of nitrogen and potassium fertilization, from harvests performed in the first production cycle, between 260 and 295 days after transplanting.

\begin{tabular}{lllllllll}
\hline \multirow{2}{*}{$\begin{array}{l}\text { Source } \\
\text { variation }\end{array}$} & of & \multicolumn{2}{l}{ Mean square } & \multicolumn{2}{l}{} \\
\cline { 2 - 9 } & $\mathrm{DF}$ & Ant & $\mathrm{Car}$ & $\mathrm{pH}$ & $\mathrm{TA}$ & $\mathrm{TSS}$ & $\mathrm{TSS} / \mathrm{TA}$ & Vit C \\
\hline Salinity $(\mathrm{S})$ & 4 & $0.00203^{\mathrm{NS}}$ & $1.68^{\mathrm{NS}}$ & $0.0443^{\mathrm{NS}}$ & $0.0108^{\mathrm{NS}}$ & $0.8468^{\mathrm{NS}}$ & $0.7198^{\mathrm{NS}}$ & $54548.99^{*}$ \\
\hline $\mathrm{NK}$ & 3 & $0.00439^{\mathrm{NS}}$ & $3.44^{\mathrm{NS}}$ & $0.0061^{\mathrm{NS}}$ & $0.0058^{\mathrm{NS}}$ & $0.1228^{\mathrm{NS}}$ & $0.3772^{\mathrm{NS}}$ & $35838.18^{\mathrm{NS}}$ \\
\hline Interaction $\mathrm{S}^{*} \mathrm{C}$ & 12 & $0.00689^{\mathrm{NS}}$ & $3.01^{\mathrm{NS}}$ & $0.0435^{\mathrm{NS}}$ & $0.0183^{\mathrm{NS}}$ & $0.7873^{\mathrm{NS}}$ & $0.8082^{\mathrm{NS}}$ & $22682.01^{\mathrm{NS}}$ \\
\hline Blocks & 2 & $0.01260^{\mathrm{NS}}$ & $6.09^{\mathrm{NS}}$ & $0.0496^{\mathrm{NS}}$ & $0.0082^{\mathrm{NS}}$ & $0.7081^{\mathrm{NS}}$ & $1.1950^{\mathrm{NS}}$ & $34036.32^{\mathrm{NS}}$ \\
\hline Residual & 38 & 0.00311 & 1.69 & 0.0237 & 0.0204 & 0.4113 & 0.5898 & 15178.90 \\
\hline $\mathrm{CV}(\%)$ & - & 0.17 & 4.23 & 4.44 & 10.16 & 7.40 & 12.35 & 8.16 \\
\hline \multirow{2}{*}{ Mean } & & $\mu \mathrm{g} \mathrm{g}^{-1}$ & ${\mathrm{mg} 100 \mathrm{~g}^{-1}}^{-1}$ & - & $\%$ A.A & ${ }^{\circ}$ brix & - & ${\mathrm{mg} 100 \mathrm{~g}^{-1}}$ \\
\cline { 2 - 9 } & - & 33.55 & 30.78 & 3.47 & 1.41 & 8.67 & 6.22 & 1510.08 \\
\hline
\end{tabular}

NS $*$ and $* *$ Not significant, significant at $\mathrm{p}<0.05$ and $\mathrm{p}<0.01$, respectively; DF - Degrees of freedom; CV - Coefficient of variation. A.A = Ácido cítrico.

Although studies evaluating the effect of the irrigation water salinity and of nitrogen and potassium fertilization on West Indian cherry fruit quality are scarce, some works have evidenced that these factors, individually, had no effect on some quality attributes in other crops. Freire et al. (2010) observed that the irrigation water salinity up to 4.5 $\mathrm{dS} \mathrm{m}{ }^{-1}$ had no effect on $\mathrm{pH}$, titratable acidity and on the total soluble solids/titratable acidity ratio of the yellow passion fruit. Likewise, Blanco and Folegatti
(2008) verified that different doses of $\mathrm{N}$ and $\mathrm{K}$, in plants irrigated with water salinity of $9.5 \mathrm{dS} \mathrm{m}^{-1}$, caused no significant effect on the concentration of total soluble solids and titratable acidity in postharvest tomato fruits.

With regard to the mean values for each parameter (Table 3), it is noted that all variables met the quality standards of the West Indian cherry fruits established by the Ministry of Agriculture, 
Fruit quality of west...

Livestock and Food Supply for fruit pulp production (BRASIL, 2000).

The mean values of the carotenoids and anthocyanin contents were $30.78 \mu \mathrm{g} \mathrm{g}^{-1}$ and 33.55 mg $100 \mathrm{~g}^{-1}$, respectively (Table 3 ), being up to 1.30 $\mu \mathrm{g} \mathrm{g}^{-1}$ and $7.62 \mathrm{mg} 100 \mathrm{~g}^{-1}$ higher than the values found in post-harvest fruits of the West Indian cherry cultivar Flor Branca (MOURA et al., 2007) due to the fruit storage time in the present study, which even under frozen conditions tended to slowly continue with the maturation process, increasing the values of these pigments, a phenomenon also observed by Araújo et al. (2009).

The mean $\mathrm{pH}$ value of the West Indian cherry fruits was 3.47 , being comparable to the 3.42 found in fruits of the cultivar Flor Branca measured soon after harvest (MOURA et al., 2007). According to Santos et al. (2012), West Indian cherry fruits usually undergo no alterations in the $\mathrm{pH}$ value, due to better conditions for the cytoplasmic metabolism within the fruits, maintaining the value of this parameter stable (SANTOS et al., 2012), a fact that maintained it within the quality standards of Brazilian regulations for the West Indian cherry pulp production, which establishes minimum $\mathrm{pH}$ value of 2.8 , and satisfies the demands of the German, American, Brazilian and Japanese markets for the pulp production of this fruit (BRASIL, 2000).

The mean total titratable acidity obtained in the West Indian cherry fruits was $1.41 \%$ of citric acid, being greater than the $0.94 \%$ found in fruits of the cultivar Flor Branca (MOURA et al., 2007). The result of the present study reveals the high acidity characteristic of this fruit, in which the value must be greater than $0.8 \%$ of citric acid (BRASIL, 2000). The maintenance of high values of citric acid in the West Indian cherry fruits is of great importance for its quality, since citric acid acts as an antioxidant
SILVA, E. M.et al.

and in maintaining the $\mathrm{pH}$ of the fruit (ARAÚJO et al., 2009).

For the concentration of total soluble solids, it is observed that the mean value was $8.7^{\circ} \mathrm{Brix}$, greater than the $5.90{ }^{\circ}$ Brix found by Moura et al. (2007) in the cultivar Flor Branca. According to the Ministry of Agriculture, Livestock and Food Supply, for fruit pulp production (BRASIL, 2000), the minimum content of soluble solids established for commercialization as pulp is $5.5^{\circ} \mathrm{Brix}$; therefore, it is affirmed that the value found in the fruits of the present study satisfies the current regulation for processing and pulp commercialization.

The mean value of the total soluble solids/titratable acidity ratio (TSS/TA) was 6.22 , similar to the value of 6.28 observed in the cultivar Flor Branca soon after fruit harvest (MOURA et al., 2007). This parameter represents one of the best standards of evaluation of the fruit flavor for its degree of sweetness; therefore, the higher this ratio is, the sweeter the fruits will be (SANTOS et al., 2012). According to Oliveira and Santos (2015), there are no defined standards of this quality parameter for West Indian cherry fruits destined for fresh consumption or industrial processing; however, the industry has increasingly looked for sweeter fruits, with a consequent higher value of this variable.

For the vitamin $\mathrm{C}$ content in the fruits, a decrease in this value by the increment in the irrigation water salinity is observed (Figure 6), with decrease of $2.16 \%$ per unit increase in the $\mathrm{ECW}$ of irrigation. Dias et al. (2011) report that the decrease in the vitamin $\mathrm{C}$ content due to the increase of salt stress is related to the reduction in the contents of soluble hexose sugars, originally D-glucose or Dgalactose, from which fruits synthesize ascorbic acid.

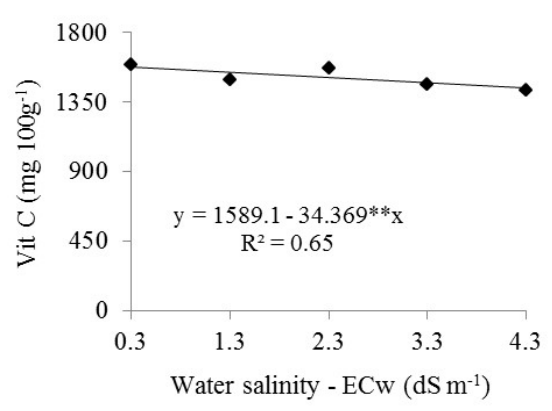

Figure 6. Vitamin C content (Vit C) in fruits of the West Indian cherry plants irrigated with saline waters, from harvests performed in the first production cycle, between 260 and 295 days after transplanting. 
According to Figure 6, it is seen that the

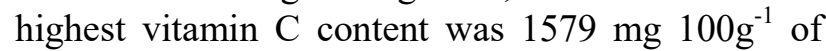
pulp in the fruits of the plants irrigated with ECw of

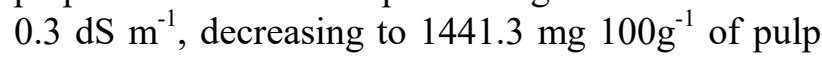
in the plants irrigated with the highest salt stress, that is, $4.3 \mathrm{dS} \mathrm{m}^{-1}$. Although salinity compromised the vitamin $\mathrm{C}$ content in the fruits, it can be considered that these values of vitamin $\mathrm{C}$ meet the minimum value of $800 \mathrm{mg} 100 \mathrm{~g}^{-1}$ of pulp established by the Ministry of Agriculture (BRASIL, 2000) and are higher than the minimum value of $1200 \mathrm{mg} 100 \mathrm{~g}^{-1}$ of pulp preferred by countries such as Japan and Germany, main importer markets for the West Indian cherry (MOURA et al. 2007). This fact might allow the irrigation of the West Indian cherry plants with ECW up to $4.3 \mathrm{dS} \mathrm{m}^{-1}$ during the first production cycle.

\section{CONCLUSIONS}

Increase in water salinity reduced the size, mass and vitamin $\mathrm{C}$ content in West Indian cherry fruits in the first production cycle; however, despite the reduction, the vitamin $\mathrm{C}$ content remained within the standards demanded by the consuming market.

The irrigation using water with electrical conductivity (ECw) of up to $4.3 \mathrm{dS} \mathrm{m}^{-1}$ and the utilization of different combinations of nitrogen and potassium combinations did not promote alterations in the fruit shape and in the contents of anthocyanin, carotenoids, $\mathrm{pH}$, titratable acidity, total soluble solids and fruit flavor, maintaining the quality standard of the fruits above the minimum values established by Brazilian regulations for the production of West Indian cherry fruit pulp.

The fertilization of the West Indian cherry plants with the $\mathrm{C} 1\left(55.42 \mathrm{~g}\right.$ of $\mathrm{N}+31.66 \mathrm{~g}$ of $\mathrm{K}_{2} \mathrm{O}$ plant $^{-1}$ year $\left.^{-1}\right)$ and $\mathrm{C} 2(79.17 \mathrm{~g}$ of $\mathrm{N}+47.50 \mathrm{~g}$ of $\mathrm{K}_{2} \mathrm{O}$ plant $^{-1}$ year $^{-1}$ ) combinations favored a greater fruit size, especially in equatorial diameter, when irrigated with ECw up to $1.3 \mathrm{dS} \mathrm{m}^{-1}$, as well as promoted a higher mass accumulation in the fruits.

The application of high $\mathrm{N}$ and $\mathrm{K}$ doses through the $\mathrm{C} 3$ (102.92 $\mathrm{g}$ of $\mathrm{N}+63.33 \mathrm{~g}$ of $\mathrm{K}_{2} \mathrm{O}$ plant $^{-1}$ year $^{-1}$ ) and C4 (126.67 $\mathrm{g}$ of $\mathrm{N}+79.16 \mathrm{~g}$ of $\mathrm{K}_{2} \mathrm{O}$ plant $^{-1}$ year $^{-1}$ ) combinations did not mitigate the salinity effects on the physical and physicochemical attributes and on the bioactive compounds of the West Indian cherry fruits, and negatively affected fruit size in the plants irrigated even with low ECw.

\section{ACKNOWLEDGMENTS}

To the Coordination for the Improvement of Higher Education Personnel (CAPES) for granting the scholarship to the first author and to the Universidade Federal de Campina Grande (UFCG/CCTA) for providing the infrastructure facilities used in the research.

RESUMO: A aceroleira se destaca entre as fruteiras cultivadas pela importância farmacológica e alimentícia de seus frutos, porém sua qualidade pode ser afetada pela salinidade da água de irrigação e o manejo da adubação. Neste sentido, objetivou-se com o trabalho estudar o efeito de diferentes salinidades da água de irrigação e de combinações de adubação nitrogenada e potássica sobre a qualidade física, físicoquímica e de compostos bioativos em frutos de aceroleira. $\mathrm{O}$ experimento foi conduzido em campo, usando lisímetros de 60 L, na Área Experimental do Centro de Ciências e Tecnologia Agroalimentar (CCTA) da Universidade Federal de Campina Grande (UFCG), Pombal, PB, em delineamento de blocos ao acaso e esquema fatorial $5 \times 4$, referentes a cinco níveis de salinidade da água de irrigação (CEa): 0,$3 ; 1,3 ; 2,3 ; 3,3$ e $4,3 \mathrm{dS} \mathrm{m}^{-1}$ e quatro combinações (C) de adubação nitrogenada e potássica: $\mathrm{C} 1=70 \% \mathrm{~N}+50 \% \mathrm{~K}_{2} \mathrm{O}$; $\mathrm{C} 2=$ $100 \% \mathrm{~N}+75 \% \mathrm{~K}_{2} \mathrm{O} ; \mathrm{C} 3=130 \% \mathrm{~N}+100 \% \mathrm{~K}_{2} \mathrm{O}$ e $\mathrm{C} 4=160 \% \mathrm{~N}+125 \% \mathrm{~K}_{2} \mathrm{O}$ da dose recomendada para aceroleira, com três repetições e uma planta por parcela constituída de um lisímetro. Estudou-se a cv. Flor Branca enxertada sobre porta-enxerto da cv. Junco, sendo a qualidade dos frutos avaliada entre 260 e 295 dias após o transplantio. O incremento na salinidade da água de irrigação reduziu o tamanho, o peso e o teor de vitamina $\mathrm{C}$ nas acerolas, porém, assim como as combinações de adubação de $\mathrm{N}$ e $\mathrm{K}$, não afetaram o formato de frutos e os teores de antocianinas, carotenoides, $\mathrm{pH}$, acidez titulável, sólidos solúveis totais e o sabor dos frutos. As combinações de adubação C1 e C2 proporcionaram o maior tamanho de frutos pela irrigação com CEa de até $1,3 \mathrm{dS} \mathrm{m}^{-1}$ e promoveram maior acúmulo de massa. Doses de fertilização acima da combinação C2 afetaram negativamente a qualidade dos frutos mesmo em plantas irrigadas com água de baixa salinidade.

PALAVRAS-CHAVE: Malpighia emarginata D. C. Salinidade. Nutrição. Pós-colheita. 


\section{REFERENCES}

ANDRADE JÚNIOR, W. P.; PEREIRA, F. H. F.; FERNANDES, O. B.; QUEIROGA, R. C. F.; QUEIROGA, F. M. Efeito do nitrato de potássio na redução do estresse salino no meloeiro. Revista Caatinga, Mossoró, v.24, n.3, p.110-119, 2011. https://periodicos.ufersa.edu.br/index.php/caatinga/article/view/2280

ARAÚJO, P. G. L.; FIGUEIREDO, R. W.; ALVES, R. E.; MAIA, G. A.; MOURA, C. F. H.; SOUSA, P. H. M. Qualidade físico-química e química de frutos de clones de aceroleira recobertos com filme de PVC e conservados por refrigeração. Semina: Ciências Agrárias, Londrina, v.30, n.4, p.867-880, 2009. http://dx.doi.org/10.5433/1679-0359.2009v30n4p867

AYERS, R. S.; WESTCOT, D. W. Qualidade da água na agricultura. 2.ed. Campina Grande: Universidade Federal da Paraíba, 1999. 153p.

BATISTA, K.; MONTEIRO, F. A. Variações nos teores de potássio, cálcio e magnésio em capim-marandu adubado com doses de nitrogênio e de enxofre. Revista Brasileira de Ciência do Solo, Viçosa, v.34, n.1, p.151-161, 2010. http://dx.doi.org/10.1590/S0100-06832010000100016

BEZERRA, I. L.; GHEYI, H. R.; NOBRE, R. G.; BARBOSA, J. L.; FÁTIMA, R. T.; ELIAS, J. J.; SOUZA, L. P.; F AZEVEDO, L. Physiological alterations and production of guava under water salinity and nitrogen fertilizer application. Semina: Ciências Agrárias, Londrina, v.39, n.5, p.1945-1956, 2018. http://dx.doi.org/10.5433/1679-0359.2018v39n5p1945

BLANCO, F. F.; FOLEGATTI, M. V. Doses de N e K no tomateiro sob estresse salino: III. Produção e qualidade de frutos. Revista Brasileira de Engenharia Agrícola e Ambiental, Campina Grande, v.12, n.2, p.122-127, 2008. http://dx.doi.org/10.1590/S1415-43662008000200003

BRASIL. Ministério da Agricultura Pecuária e Abastecimento. Instrução normativa $\mathbf{n}^{\circ} \mathbf{1}$ de 07 de janeiro de 2000. Padrão de identidade e qualidade para polpas de frutas.

CAlGARO, M.; BRAGA, M. B. A cultura da acerola. 3.ed. Brasília, DF: Embrapa, 2012. 144 p. (Coleção Plantar; 69).

CAVALCANTI, F. J. Recomendações de adubação para o Estado de Pernambuco: 2. aproximação. 2.ed. Recife: IPA, 2008. 212p.

DIAS, T. J.; CAVALCANTE, L. F.; FREIRE, J. L. O.; NASCIMENTO, J. A. M.; BECKMANN-

CAVALCANTE, M. Z.; SANTOS, G. P. Qualidade química de frutos do maracujazeiro-amarelo em solo com biofertilizante irrigado com águas salinas. Revista Brasileira de Engenharia Agrícola e Ambiental, Campina Grande, v.15, n.3, p.229-236, 2011. http://dx.doi.org/10.1590/S1415-43662011000300002

FACHI, L. R.; FERREIRA, A. F. N.; GARBUGIO, E. L. S.; KRAUSE, S.; KRAUSE, W. Qualidade e correlação dos parâmetros físico-químicos dos frutos de cultivares de acerola. Enciclopédia Biosfera, Goiânia, v.13 n.24, p.890-897, 2016. www.conhecer.org.br/enciclop/2016b/agrarias/Qualidade\%20e\%20correlacao.pdf. https://doi.org/10.18677/EnciBio_2016B_084

FERREIRA, D. F. Sisvar: um sistema computacional de análise estatística. Ciência e Agrotecnologia, Lavras, v.35, n.6, p.1039-1042, 2011. http://dx.doi.org/10.1590/S1413-70542011000600001

FERREIRA, K. S. Crescimento e acúmulo de nutrientes em mudas de aceroleira adubadas com nitrogênio e potássio. 2014. 49 f. Dissertação (Mestrado em Ciências Agrárias) - Curso de Pós-Graduação em Ciências Agrárias, Universidade Federal de São João Del-Rei, São João Del-Rei, 2014. 
FREIRE, J. L. O.; CAVALCANTE, L. F.; REBEQUI, A. M.; DIAS, T. J.; NUNES, J. C.; CAVALCANTE, Í. H. L. Atributos qualitativos do maracujá amarelo produzido com água salina, biofertilizante e cobertura morta no solo. Revista Brasileira de Ciências Agrárias, Recife, v. 5, n.1, p.102-110, 2010.

http://dx.doi.org/10.5039/agraria.v5i1a674

GURGEL, M. T.; UYEDA, C. A.; GHEYI, H. R.; OLIVEIRA, F. H. T. DE; FERNANDES, P. D.; SILVA, F. V. Crescimento de meloeiro sob estresse salino e doses de potássio. Revista Brasileira e Engenharia Agrícola e Ambiental, Campina Grande, v.14, n.1, p.3-10, 2010. http://dx.doi.org/10.1590/S1415-43662010000100001

INMET - Instituto Nacional de Meteorologia. Estações e dados. Disponível em:

http://www.inmet.gov.br/portal/index.php?r=estacoes/estacoesAutomaticas. Acesso em: 03 mar. 2018.

INSTITUTO ADOLFO LUTZ. Normas analíticas do Instituto Adolfo Lutz. 4.ed. Campinas: IAL, 2008.

INTHICHACK, P.; NISHIMURA, Y.; FUKUMOTO, Y. Effect of potassium sources and rates on plant growth, mineral absorption and the incidence of tip burn in cabbage, celery, and lettuce. Horticulture, Environment, and Biotechnology, Busan, v.53, n.2, p.135-142, 2012. https://doi.org/10.1007/s13580-0120126-Z

MEDEIROS, J. F. Qualidade da água de irrigação e evolução da salinidade nas propriedades assistidas pelo "GAT" nos Estado do RN, PB e CE. 1992. 173 f. Dissertação (Mestrado em Engenharia Agrícola) Curso de Pós-Graduação em Engenharia Agrícola, Universidade Federal da Paraíba, Campina Grande, 1992.

MOURA, C. F. H.; ALVES, R. E.; FIGUEIREDO, R. W.; PAIVA, J. R. Avaliações físicas e físico-químicas de frutos de clones de aceroleira (Malpighia emarginata D.C.). Revista Ciência Agronômica, Fortaleza, v.38, n.1, p.52-57, 2007. Disponível em: http://ccarevista.ufc.br/seer/index.php/ccarevista/article/view/149. Acesso em: 23 jan. 2019.

NIVAS, D.; GAIKWAD, D. K.; CHAVN, P. D. Physiological responses of two morinda species under saline conditions. American Journal of Plant Physiology, New York, v.6, n.3, p.157-166, 2011.

https://doi.org/10.3923/ajpp.2011.157.166

OLIVEIRA, E. N. A.; SANTOS, D. C. A Tecnologia e processamento de frutos e hortaliças. Natal: IFRN, 2015. 234p.

SÁ, F. V. S.; GHEYI, H. R.; LIMA, G. S.; PAIVA, E. P.; MOREIRA, R. C. L.; SILVA, L. A. Water salinity, nitrogen and phosphorus on photochemical efficiency and growth of West Indian cherry. Revista Brasileira de Engenharia Agrícola e Ambiental, Campina Grande, v.22, n.3, p.158-163, 2018.

http://dx.doi.org/10.1590/1807-1929/agriambi.v22n3p158-163

SANTOS, S. M. L.; VASCONCELOS, A. M.; OLIVEIRA, V. S.; CLEMENTE, E.; COSTA, J. M. C. Evaluation of physical and physicochemical characteristics of Malpighia emarginata D.C. from the state of Ceará. International Journal of Biochemistry Research \& Review, London, v. 2, n.4, p.152-163, 2012. http://dx.doi.org/10.9734/IJBCRR/2012/1945.

SIMS, D. A.; GAMON, J. A. Relationships between leaf pigment content and spectral reflectance across a wide range of species, leaf structures and developmental stages. Remote Sensing of Environment, New York, v.81, p.337-354. 2002. https://doi.org/10.1016/S0034-4257(02)00010-X

TAIZ, L.; ZEIGER, E.; MØLLER, I. M.; MURPHY, A. Fisiologia e desenvolvimento vegetal. 6.ed. Porto Alegre: Artmed, 2017. 858p.

VIDIGAL, S. M.; PACHECO, D. D.; COSTA, E. L. DA; FACION, C. E. Crescimento e acúmulo de macro e micronutrientes pela melancia em solo arenoso. Revista Ceres, Viçosa, v.56, p.112-118, 2009. Disponível em: www.ceres.ufv.br/ojs/index.php/ceres/article/view/3404. Acesso em: 18 jan. 2019. 
WANG, M.; ZHENG, Q.; SHEN, Q.; GUO, S. The critical role of potassium in plant stress response. International Journal Molecular Sciences, Basel, v. 14, n. 4, p. 7370-7390, 2013.

https://doi.org/10.3390/ijms14047370

WILLADINO, L.; CAMARA, T. R. Tolerância das plantas à salinidade: Aspectos fisiológicos e bioquímicos. Enciclopédia Biosfera, Goiânia, v.6, n.11; p.1-23, 2010. Disponível em:

www.conhecer.org.br/enciclop/2010c/tolerancia\%20das\%20plantas.pdf. Acesso em: 15 jan. 2019. 